\title{
Project-Based Learning in the Teaching of English as A Foreign Language in Greek Primary Schools: From Theory to Practice
}

\author{
Iosif Fragoulis \\ Tutor Hellenic Open University
}

Iakovos Tsiplakides (Corresponding author)

Department of Philosophy, Education and Psychology, University of Ioannina

Iakovos Tsiplakides, Nikis Street, 45221, Ioannina, Greece

Tel: 30-265-109-5775Ｅ-mail: address: tsiplakides@hotmail.com

Iakovos Tsiplakides receives a scholarship from the State Scholarships Foundation in Greece

\begin{abstract}
This article deals with implementing project work in the teaching of English as a foreign language in Greek state primary schools. Theoretical foundations for project-based learning are presented and applied in the classroom, difficulties encountered are discussed, and benefits resulting from student participation in project work are suggested. The article purports to be pragmatic in focus, linking theory with practice, and providing practitioners with a tool for effectively implementing project-based learning in foreign language contexts.
\end{abstract}

Keywords: Project-based learning, English as foreign language in Greece

\section{Introduction}

Experiential learning refers to the organization of the learning process on the basis of the pedagogical principle of "learning by doing", which means that learners acquire knowledge after having experienced or done something new (Kotti, 2008:32). Experiential learning is defined as the exploitation and processing of experience, aiming not only at acquiring knowledge, but also at transforming the way of thinking and changing attitudes (Mezirow, 1991). In experiential learning learners participate "in concrete activities that enable them to 'experience' what they are learning about" and the "opportunity to reflect on those activities" (Silberman, 2007:8), since "learning is the process whereby knowledge is created through the transformation of experience" (Kolb, 1984).

Experiential learning is related to the project method. The project method is "a natural extension of what is already taking place in class" (Stoller, 2002:109), an open learning process, the limits and processes of which are not strictly defined, which progresses in relation to the specific teaching context and learners' needs and interests. (Frey, 1986; Kriwas, 2007).

The project method originates from Pragmatism, the philosophical movement which appeared in the middle of the $19^{\text {th }}$ century and promotes action and practical application of knowledge in everyday life (Frey, 1986:31). Major proponents of Pragmatism are J. Dewey (1935) and W. Kilpatrick (1935) in the U.S.A, and H.Gaudig and G. Kerschensteiner in Germany.

The implementation of the project method was based on the following pedagogical principles, expressed by many progressive educators (Chrysafidis, 2005): a) promotion of manual activity instead of memorization and verbalism, b) learners' active participation in the learning process, and c) exploitation of facts relating to the immediate reality as a source for learning.

The project method was linked to the internal reform of the educational process, basic components of which are the following: a) opening of school to the local community, b) provision of equal opportunities to all students regardless of socioeconomic background, c) exploitation of immediate space as departure for learning, d) systematic study of problems of everyday life at school, e) cross-curricular approach to knowledge (Vrettos and Kapsalis, 1997, Papagiannopoulos et al, 2000).

\section{Benefits of project work in second and foreign language settings}

Many benefits of incorporating project work in second and foreign language settings have been suggested. First, the process leading to the end-product of project-work provides opportunities for students to develop their confidence and independence (Fried-Booth, 2002). In addition, students demonstrate increased self-esteem, and positive attitudes toward learning (Stoller, 2006:27). Students' autonomy is enhanced (Skehan, 1998), especially when they are actively 
engaged in project planning (e.g. choice of topic). A further frequently mentioned benefit relates to students' increased social, cooperative skills, and group cohesiveness (Coleman, 1992; Papagiannopoulos et al, 2000: 36-37).

Another reported benefit is improved language skills (Levine, 2004). Because students engage in purposeful communication to complete authentic activities, they have the opportunity to use language in a relatively natural context (Haines, 1989) and participate in meaningful activities which require authentic language use. Authentic activities refer to activities designed to develop students' thinking and problem solving skills which are important in out-of-schools contexts, and to foster learning to learn (Brown et al, 1993). While activities are 'Anything students are expected to do, beyond getting input through reading or listening, in order to learn, practice, apply, evaluate, or in any other way respond to curricular content' (Brophy and Alleman,1991), authentic activities are tasks with real world relevance and utility, "that integrate across the curriculum, that provide appropriate levels of complexity, and that allow students to select appropriate levels of difficulty or involvement" (Jonassen, 1991), as quoted in Herrington et al, 2003). Among other characteristics, authentic activities have real-world relevance, provide the opportunity for students to examine the task from different perspectives, enhance collaboration and reflection, and allow competing solutions and diversity of outcome (Reeves et al, 2002). In addition, project-based learning provides opportunities for "the natural integration of language skills" (Stoller, 2006:33).

A further benefit is that because project work progresses according to the specific context and students' interests (Kriwas, 1999:149), students have enhanced motivation, engagement and enjoyment (Lee, 2002). From a motivational perspective, projects being authentic tasks, are more meaningful to students, increase interest, motivation to participate, and can promote learning (Brophy, 2004). Enjoyment and motivation also stem from the fact that classroom language is not predetermined, but depends on the nature of the project (Larsen-Freeman, 2000:149).

Another set of reported benefits pertains to the development of problem-solving and higher order critical thinking skills (Allen, 2004). These skills are very important, since they are life-long, transferable skills to settings outside the classroom.

Finally, according to Dornyei (2001:100-101), among other potential benefits, project work encourages motivation, fosters group cohesiveness, increases expectancy of success in target language, achieves "a rare synthesis of academic and social goals", reduces anxiety, increases the significance of effort relative to ability, and promotes effort-based attributions.

\section{Teacher role in project-based learning}

Effective project-based learning requires the teacher to assume a different role (Levy, 1997). The teacher's role is not dominant, but he/she acts as a guide, advisor, coordinator (Papandreou, 1994), and facilitator. In implementing the project method, the focal point of the learning process moves from the teacher to the learners, from working alone to working in groups.

\section{Stages in project work}

The following general stages can be used for successful project implementation. They constitute a practical guide for the sequencing of project activities for teachers who want to implement projects in their classrooms (Kriwas, 1999).

\subsection{Stage 1: Speculation}

This stage includes choice of project topic and sensitisation about it, aiming at arousing interest and developing a climate conductive to speculation and investigation that will lead smoothly to the research process. Topic is chosen after a dialogue among all members of the group, and the teacher. The initial stimulus may emerge from the curriculum, or after a discussion about a contemporary local or wider topic of interest, or from reading a newspaper or magazine article (Brinia, 2006: 79).

\subsection{Stage 2: Designing the project activities}

This stage includes formation of groups and assigning of roles, decisions concerning methodology, sources of information, activities that will take place, and places outside the classroom that students will visit. The better organised and more analytical the structuring of the activities, the easier and faster the research will be conducted (Fragoulis, 2008).

\subsection{Stage 3: Conducting the project activities}

At this stage the groups implement the activities designed in the previous stage. Students gather information, process and categorize it. If deemed necessary, there may be intervals of information and feedback, in which students discuss issues related with cooperation among group members, problems of personal relations, and possible changes in group composition.

The next phase is synthesis and processing of information gathered. The final products are displayed in the school or the wider community, and become a stimulus for thought and action for other students, teachers and local community. The 
project moves away from school and becomes social intervention, connecting the school with the community and real life (Fragoulis, 2008:35).

\subsection{Stage 4: Evaluation}

Evaluation refers to the assessment of the activities from participants and discussion about whether the initial aims and goals have been achieved, implementation of the process, and final products (Brinia, 2006:82). Evaluation also entails assessment of the experience at individual and group level, identification of errors and problems, but also appraisal of the rich cognitive and experiential material gathered. Evaluation includes evaluation from others, as well as self-evaluation.

Although there are many studies focusing on the theoretical underpinnings for project-based learning in foreign language teaching, there are relatively few empirical studies linking theory with practice, evaluating the impact of project work in the context of foreign language instruction. In this context, our study examines the practical aspects of implementing project work in primary school settings, reporting difficulties encountered, benefits from project work, and pedagogical implications.

\section{A case study of project work: from theory to practice}

\subsection{Participants}

Fifteen sixth grade primary school students, aged 11-12 years, in a village in the prefecture of Achaia in Greece took part in the project. Two primary school teachers participated, a school teacher, who had experience in the implementation of modern teaching methods, and the teacher of English. The project lasted six months and students worked on it for two hours per week, in the framework of day long school.

\subsection{Goals of project work}

The overarching aim was to implement project work in order to make students aware of the history of the area in which they live, and use it as a mechanism for cross curricular, and interdisciplinary work, as well as to make use of new technologies. The specific aims were:

\section{Cognitive aims}

1) To help students learn about the history of their village and the wider area.

2) To help students realize the significance of the historical and natural environment in relation to the sustainable development of the area.

3) To improve students' reading, writing, listening, speaking, vocabulary skills, and communicative competence.

4) Emotional aims

5) To sensitize students about the problems connected with the development of the area.

6) To foster respect about the collaborative efforts of people who lived in the specific geographical area.

7) Psychomotor aims:

8) To acquaint students with observation and research.

9) To foster the development of curiosity and observation skills to students.

\subsection{Sequence of project activities}

Drawing on Stoller (2002), the following six stages were followed. The first step included choosing the topic of the project and agreeing on the final outcomes. The project topic was "local history", and it was determined by both the teacher and the students, since it was a semi-structured project (Henry, 1994). The term "local history" refers to the total social, cultural, financial and political history of a specific region in relation to the history of the wider geographical region of which it is part, but also in relation to the national and global history (Papagiannopoulos et al, 2007:17).

Choice of topic for research was based on the following criteria: a) the topic forms part of the immediate students' experiences, b) it is close to their interests, needs and their everyday problems, c) it creates the conditions necessary for investigating, interpreting and critically analysing the world. Students study local history, come into contact with the problems of the area and approach them diachronically, make judgements, analyse and compare information, so they gradually acquire historical awareness.

In the second stage teachers and students structured the project work. This included determining information required, sources of information, how analysis of information will take place, formation of project groups on the basis of the students' interests and needs, and assigning roles and coordinators for each group. The following principles were applied in relation to group formation and function (Brophy, 2008:161): a) tasks were at such level of difficulty that students could complete with reasonable effort, b) each group member was allocated some specific responsibilities, c) 
each group had a goal and motivation to work toward the goal, and d) the teacher checked the progress of groups at regular intervals, providing progress and corrective feedback.

The third stage included the gathering of information from a variety of sources. The process and study of issues related with local history was attempted through the cross curricular - interdisciplinary approach. The following activities were implemented:

- Search in a variety of information sources (magazines, newspapers, the Internet, and libraries).

- Field trip to Patras to interview individuals who are engaged, either directly or indirectly with the operation of the port of Patras.

- Collection of articles, fictional texts, myths and legends about the area.

The fourth stage included analysis of data gathered, that is, selection of appropriate information and discarding of irrelevant material. The fifth stage was presentation of the final products, which included:

- Creation of a topographic map.

- Creation of an album with photographs and comments depicting the "positive" and "negative" human interventions in the area.

- Creation of a brochure about the importance of protecting the area and its ecosystem.

- PowerPoint presentation.

- Organization of an event directed towards the local community, presenting the final products from project work.

The final stage included evaluation of the project. Evaluation was expressed positively and not negatively, because the aim was to reflect on language and content mastered, effectiveness of steps and activities used (Stoller, 2002; Fragoulis, 2008:54). The focus is on whether and to what extent knowledge, experiences, and skills acquired formed new values and attitudes that changed or substituted old negative attitudes. These transformations constitute the essence of real learning (Mezirow, 1991).

Finally, it is worth mentioning that the above activities implemented in the context of project work do not constitute "ideal" or "correct" classroom practices. English teachers should be aware that what is successful in one teaching situation might be inappropriate in another. We simply wish the project presented here to become a starting point for teachers to reflect in relation to their students' needs and interests, and motivate them to incorporate new interactive teaching methods in order to make teaching more attractive and keep up with the social reality (Fragoulis and Mega, 2009).

\section{Benefits from project work}

Most cognitive, emotional and psychomotor aims (see section 5.2) of project work were achieved by the majority of students. More specifically, in relation to language skills, most learners' willingness to participate in learning activities increased. They were more eager to experiment with new language, since they were less concerned with "sounding silly" (Lightbown and Spada, 1999:31). At the end of the school term, most students showed an improvement in all four language skills. Their speaking and listening skills, in particular, had the greatest improvement. This was particularly important, since it is not uncommon for students to have good knowledge of the linguistic system of the target language, but little listening comprehension and speaking skills, because they are not provided with opportunities to participate in real and authentic communication activities.

As far as motivation is concerned, findings seem to support the view expressed in many studies that project work results in enjoyment and sense of self-esteem (Levine, 2004). For some students with low performance, however, increased self-esteem seemed to last only for the duration of the project. It seems, therefore, that project work alone cannot adequately address issues of self-esteem. Most importantly, however, most students seemed to have developed intrinsic motivation, participating in learning activities for "the spontaneous feelings of interest and enjoyment" (Deci and Moller, 2005:582). As what a low performing student said: "I really liked it (the project) I wish we did it more often".

In addition, students gathered a wealth of information about local history from a variety of sources (books, interviews, and the internet), learned a lot about local history, and gained in-depth understanding of issues related to local history. These findings are similar to findings suggesting the development of content knowledge through project work (Gu, 2004).

Most students' communicative competence developed, mainly discourse competence, that is, the ability to connect sentences to form a meaningful whole, and strategic competence, "the verbal and non-verbal communication strategies that may be called into action to compensate for breakdowns in communication due to performance variables or due to insufficient competence" (Canale and Swain, 1980). Their grammatical competence "knowledge of lexical items and of 
rules of morphology, syntax, sentence-grammar semantics and phonology" (ibid), and sociocultural competence (using language in a social context) showed less improvement, though.

Their social skills and collaborative skills improved dramatically, which is consistent with findings in other studies (Coleman, 1992). After the project work students knew that being a team member entailed certain obligations, most of them developed skills for solving in-group conflicts, and learned to be responsible in relation to the roles assigned to them. Most importantly, all students, regardless of language performance, or motivational intensity seemed to have developed their cooperative skills. Also, their computer skills improved, mainly, the ability to use the internet to search for information.

\section{Difficulties encountered}

The most serious problem related to the fact that students were not familiar with group work. At the beginning, although clear roles for group members were assigned, some students dominated the work, while others did little work. Also, some students did not use the target language for communication, but their mother tongue. The teachers remedied these problems by providing cognitive modeling, completing a task while thinking aloud, modeling and illustrating effective strategies and procedures for task completion.

Another difficulty concerned the fact that some students felt that the duration of the project was too long. Some students seemed to have lost interest and motivation by the end of the project. It seems that short-term projects may have more validity for primary school learners than long-term ones.

Finally, some students had difficulty accepting the new role of the teacher as a facilitator and coordinator, and not as a source of knowledge and provider of solutions. At the beginning of project work some students felt uncomfortable with being given choices (e.g. topic selection, team formation), and were thus apprehensive about project work. However, most of them soon realized that the teacher was there to support and assist them, albeit in a different way.

\section{Discussion and conclusion}

It is important to acknowledge a limitation of this study. Due to the small number of participants, and the fact that we present findings from just one case study, care should be taken in generalizing the research findings.

The activities presented in the article are a different way of teaching local history and English as a foreign language, adopting the pedagogical principle of exploratory learning. Students acquire knowledge through a process of "building" it, form groups, cooperate, use authentic, "real" information sources, process and evaluate them, take initiatives, and make decisions. They develop autonomy because they have choices and develop a sense of control and responsibility for their learning, approaching learning in a way that suits their "abilities, styles and preferences" (Skehan, 1998: 273).

The teachers who implemented the project stated that their experience gained was extremely important. Despite problems of school infrastructure and resources available, and lack of experience in project work, their initial fears and insecurity were finally overcome. They evaluated positively the potential offered by the project method and expressed the need for their systematic training in the method.

An implication for further research is to examine the relation between short-term project work and students' communicative competence, and the effect of projects on the self-esteem of students with low performance.

The pedagogical implications are clear. Education is not offered with impersonal teaching methods and educational tools. The teacher is indispensable source of inspiration and encouragement, a "living example" to students. In addition, knowledge of modern teaching methods, and willingness to experiment with non-traditional teaching practices are powerful tools for the achievement of teaching aims, such as increased motivation, interest, and performance in the hands of teachers in the context of English as a foreign language instruction.

\section{References}

Allen, L., Q. (2004). Implemending a culture portfolio project within a constructivist paradigm. Foreign Language Annals, 37, 232-239.

Brinia,V. (2006). Experiential learning in the subject "Organisation and business administration" in general upper secondary school: A suggestion for effective education. [Online] Available: http://www.pi-schools.gr (April 24, 2009) (in Greek).

Brophy, J. (2004). Motivating Students to Learn. New Jersey: Lawrence Erlbaum Associates.

Brophy, J., \& Alleman, J. (1991). Activities as instructional tools: A framework for analysis and evaluation. Educational Researcher, 20(4), 9-23.

Brown, A., L., Ash, D., Rutherford, M., Nakagawa, K., Gordon, A., \& Campione, J., C. (1993). Distributed expertise in the classroom. In G. Salomon (Ed.), Distributed cognitions: Psychological and educational considerations (pp. 188-228). Cambridge: Cambridge University Press. 
Canale, M. \& Swain, M. (1980). Theoretical bases of communicative approaches to second language teaching and testing. Applied Linguistics, 1(1), 1-47.

Coleman, J. A. (1992). Project-based learning, transferable skills, information technology and video. Language Learning Journal, 5, 35-37.

Crisafidis, K. (2005). Experiential-communicative teaching. Implementing the project method in school. Athens: Gutenberg. (in Greek).

Deci, E., L., \& Moller, A., C. (2005). The concept of competence: A starting place for understanding intrinsic motivation and self-determined extrinsic motivation. In A. J. Elliot \& C. S. Dweck (Eds.), Handbook of competence and motivation (pp. 579-597). New York: Guildford Press.

Dörnyei, Z. (2001). Motivational Strategies in the Language Classroom. Cambridge: Cambridge University Press.

Fragoulis, I. (2008). Notes on environmental education, Patras, Primary Teachers' in-service training college, University of Patras. (in Greek).

Fragoulis, I, \& Mega, G. (2009). The project method and visible thinking: A comparative study. Presentation in the $1^{\text {st }}$ Panhellenic Conference of Educational Sciences, 28-31 may, 2009. (in Greek).

Frey, K. (1986). The project method, Thessaloniki, Kyriakidis. (in Greek).

Fried-Booth, D., L. (2002). Project work (2nd ed.). New York: Oxford University Press.

Gu, P. (2004). Tech view: Leaving the bathtub to make waves. Essential Teacher, 1(4), 32-35.

Haines, S. (1989). Projects for the EFL classroom: Resource material for teachers. Walton-on-Thames, UK: Nelson.

Henry, J. (1994). Projects for the EFL classroom: Resource material for teachers. Walton-on-Thames Surrey, UK: Nelson.

Herrington, J., Oliver, R., and Reeves,

T.,C. (2003). Patterns of engagement in authentic online learning environments, Australian Journal of Educational
Technology, 19(1), 59-71.
Jonassen, D. (1991). Evaluating constructivistic learning.

Educational Technology, 31(9), 28-33.

Kolb, D. A. (1984). Experiential Learning: Experience as the Source of Learning and Development. Englewood Cliffs, NJ: Prentice-Hall.

Kotti, D. (2008). Experiential learning from theory to practice. Adult Education, 13, 35-41. (in Greek)

Kriwas, S. (1999). Environmental education, a handbook for educators. Athens: Ministry of Education. (in Greek).

Kriwas, S. (2007). Pedagogical science. Basic themes. Athens: Gutenberg. (in Greek).

Larsen-Freeman, D. (2000). Techniques and principles in language teaching. Oxford: Oxford University Press.

Lightbown, P. \& Spada, N. (1999). How Languages are Learned (2nd ed.). Oxford: Oxford University Press.

Lee, I. (2002). Project work made easy in the English classroom. Canadian Modern Language Review, 59, $282-290$.

Levine, G., S. (2004). Global simulation: a student-centered, task-based format for intermediate foreign language courses. Foreign Language Annals, 37, 26-36.

Levy, M. (1997) Project-based learning for language teachers: reflecting on the process. In R. Debski, J. Gassin, \& M. Smith (Eds.), Language learning through social computing, (pp. 181-191). Melbourne: Applied Linguistic Association of Australia and Horwood Language Center.

Mezirow, J. (1991). Transformative Dimensions of Adult Learning. San Francisco: Jossey-Bass.

Papadakis, S., Velissarios, A., \& Fragoulis, I. (2003). Implementation of ICT in the teaching of lical history in day long school. A teaching approach in the framework of cross curricular - approach, paper presented at the 2nd Hellenic Conference for the exploitation of ICT in teaching practice", Syros, 9-11 May, 2003. (in Greek).

Papagiannopoulos, K. Simoni, E, and Fraggoulis, I. (2000). Local history in the framework of teaching, Athens: OEDB. (in Greek).

Papandreou, A., P. (1994). An application of the projects approach to EFL. English teaching Forum, 32(3), 41-42.

Reeves, T.C., Herrington, J., \& Oliver, R. (2002). Authentic activities and online learning. In A. Goody, J. Herrington \& M. Northcote (Eds.), Quality conversations: Research and Development in Higher Education, Volume 25 (pp. 562-567). Jamison, ACT: HERDSA.

Skehan, P. (1998). A cognitive approach to language learning. Oxford: Oxford University Press. 
Stoller, F. (2002). Project Work: A Means to Promote Language and Content. In Jack, C. Richards \& Willy, A. Renandya (Eds.) Methodology in Language Teaching: an anthology of Current Practice (pp. 107-120). Cambridge: Cambridge University Press.

Stoller, F. (2006). Establishing a theoretical foundation for project-based learning in second and foreign language contexts. In Beckett, G., H. \& P. C. Miller (Eds.), Project-Based Second and Foreign Language education: past, present, and future (pp. 19-40). Greenwich, Connecticut: Information Age Publishing.

Silberman, M. (2007). The Handbook of Experiential Learning. San Francisco: Pfeiffer.

Vrettos, I. \& Kapsalis, A. (1997). Curriculum. Athens: Greek Letters. (in Greek). 